\title{
THERMAL EFFECTS OF CREVASSING ON STEELE GLACIER, YUKON TERRITORY, CANADA
}

\author{
By Gary T. Jarvis and Garry K. C. Clarke \\ (Department of Geophysics and Astronomy, University of British Columbia, Vancouver 8, \\ British Columbia, Canada)
}

\begin{abstract}
Ice temperature measurements have been made in Steele Glacier to a depth of ${ }_{114} \mathrm{~m}$. All measured temperatures were below $0^{\circ} \mathrm{C}$, the coldest being $-6.5^{\circ} \mathrm{C}$ at a depth of $114 \mathrm{~m}$. The temperature profile indicates an anomalously warm layer of ice between $30 \mathrm{~m}$ and $50 \mathrm{~m}$, which is probably due to the freezing of water in crevasses opened during the $1965-66$ surge. A two-dimensional model of a cold glacier with partially water-filled crevasses predicts temperature profiles very similar to that observed.

RÉsumÉ. Effet thermique de la présence de crevasses sur le Steele Glacier, Territoire du Yukon, Canada. Des mesures de températures ont été faites sur le Steele Glacier jusqu'à une profondeur de $114 \mathrm{~m}$. Toutes les températures mesurées étaient négatives, les plus froides étant $-6,5^{\circ} \mathrm{C}$ à une profondeur de $114 \mathrm{~m}$. Le profil des températures montre un réseau de glace anormalement chaud entre 30 et $50 \mathrm{~m}$, qui est probablement dû au regel d'eau dans les crevasses ouvertes pendant la crue de $196_{5}-66$. Un modèle bidimensionnel de glacier froid avec des crevasses partiellement remplies d'eau fait prévoir des profils de température très semblables à ceux observés.

Zusammenfassung. Thermische Wirkung der Spaltenbildung am Steele Glacier, Yukon Territory, Kanada. Im Steele Glacier wurden Eistemperaturen bis zu einer Tiefe von 1 i $4 \mathrm{~m}$ gemessen. Alle Temperaturen lagen unter $0^{\circ} \mathrm{C}$, die tiefste betrug $-6,5^{\circ} \mathrm{C}$ in $114 \mathrm{~m}$ Tiefe. Das Temperaturprofil weist auf eine ungewöhnlich warme Eisschicht zwischen $30 \mathrm{~m}$ und $50 \mathrm{~m}$ hin, die vermutlich auf das Gefrieren von Wasser in Spalten zurückzuführen ist, die sich während des Ausbruches von 1965/66 geöffnet haben. Ein zweidimensionales Modell eines kalten Gletschers mit teilweise wassergefüllten Spalten lässt Temperaturprofile erwarten, die dem beobachteten sehr ähnlich sind.
\end{abstract}

\section{INTRODUCTION}

The Steele Glacier is a large valley glacier in the St Elias Mountains, Yukon Territory, Canada. Explorations by Wood (1936) and Sharp (195I) indicate that for at least thirty years prior to 1965 , the $10-15 \mathrm{~km}$ lower zone was inactive and provided a safe, relatively uncrevassed route into the Icefield Ranges. Austin Post finds photographic evidence for "an extensive surge which severely fractured the surface of the upper glacier" around I $94^{\circ}$ and "must have faded out near the 'big bend' of the Steele", some $12 \mathrm{~km}$ from the present terminus (personal communication from M. F. Meier). By summer 1966 Steele Glacier was in the midst of a spectacular surge which displaced surface features $8 \mathrm{~km}$ within one year. Premonitory signs, apparent on aerial photographs, led Post in I96o to predict the Steele's surge, but unfortunately none witnessed the onset of the active phase. Stanley (1969) and Meier (personal communication) refer to aerial photographs, taken by Post in the summer of 1965 , which show extensive crevassing of the glacier surface, and indicate the advance probably began in 1965. From August 1966 the surge is well documented (Bayrock, 1967; Stanley, 1969; Wood, 1967[a], [b]; Thomson, 1972) and Wood (1972) has published an historical review containing striking pre-surge and post-surge photographs.

The cause of the Steele surge is unknown, but as the nearby Rusty and Trapridge Glaciers appear to surge by a thermal instability mechanism, temperature measurements in Steele Glacier could prove diagnostic. Consequently in July 1972 a reconnaissance program of icetemperature measurement was begun and a single hole was thermally drilled to a depth of I $14 \mathrm{~m}$ in the central region of the glacier (Fig. I). Two eight-conductor cables attached to the power cable of the thermal probe carried thirteen calibrated thermistors to depths ranging from $25 \mathrm{~m}$ to $\mathrm{I} 14 \mathrm{~m}$. The drilling and temperature measurement procedures were essentially the same as those described by Classen and Clarke (1972). Thermistor resistances were measured ten days after the termination of drilling and converted to ice temperatures. 


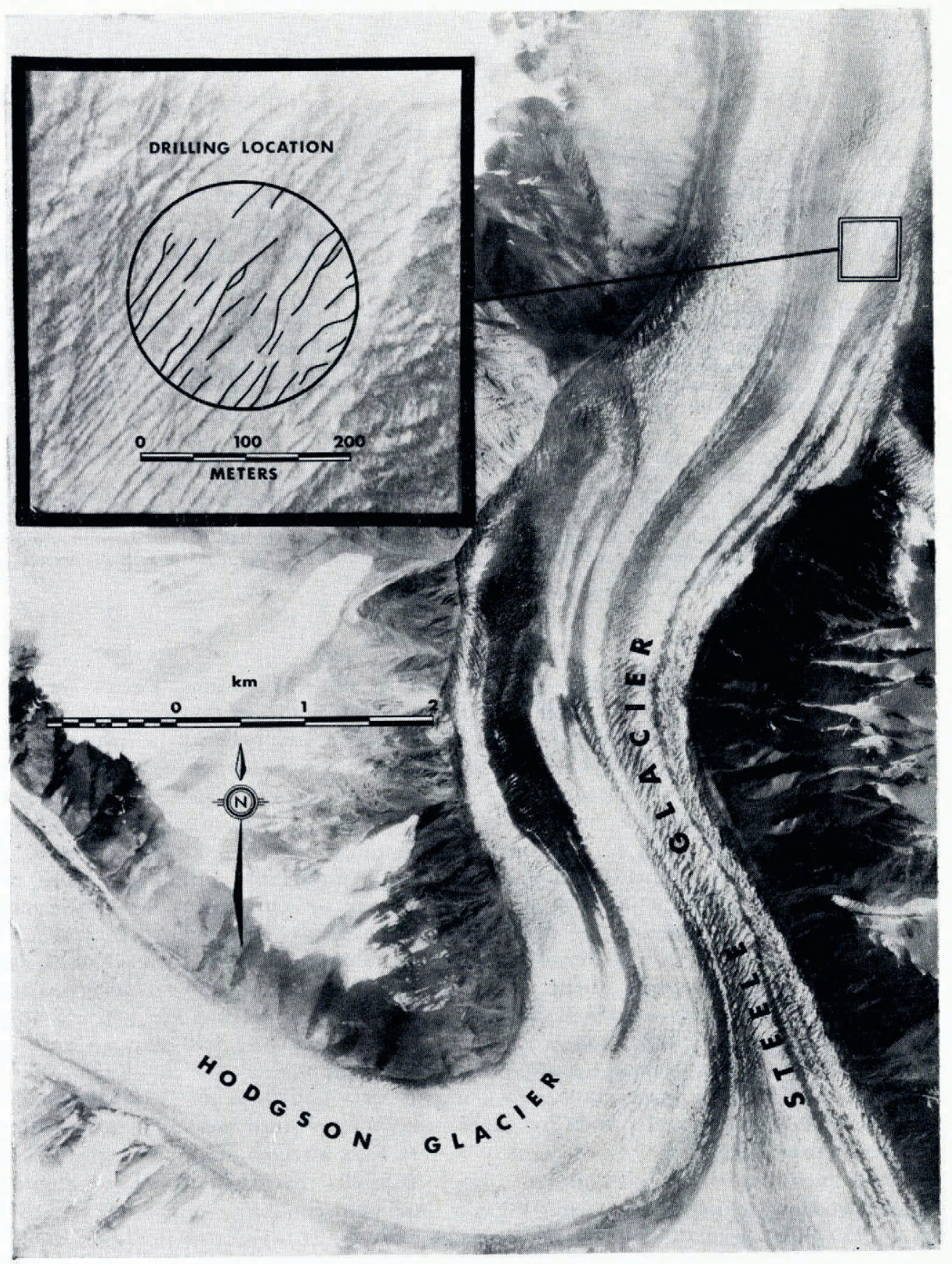

Fig. I. Portion of Canadian Government air photograph A2I523-73 showing confluence region of Steele and Hodgson Glaciers. Inset shows details of crevasses near drilling site. 
Cooling curves obtained from holes drilled with thermal probes of various diameters on the nearby Trapridge Glacier show that thermal equilibrium is not reached in ten days. To correct the measured temperatures, theoretical cooling curves were computed. The diffusion equation was solved in cylindrical polar coordinates, by finite-difference methods, for a water-filled cylindrical hole in cold ice (Appendix A). The solution yields both hole closure and ice temperature as a function of time, and the resulting cooling curves can be compared to observational data if the initial hole radius is known. The thermal probe radius is not a good estimate of the initial hole radius because the probe efficiency is not $100 \%$. A better estimate of this radius is obtained by assuming that all the thermal energy from the probe is used to melt ice. For drilling speed $v_{\mathrm{p}}$ the radius of the hole $r_{\mathrm{c}}$ can be calculated as

$$
r_{\mathrm{c}}=\left(P / L \rho \pi v_{\mathrm{p}}\right)^{\frac{1}{2}}
$$

where $P$ is the input power to the probe, $L$ the latent heat of fusion $\left(3.337 \times 10^{5} \mathrm{~J} / \mathrm{kg}\right)$, and $\rho$ the ice density. As both $P$ and $v_{\mathrm{p}}$ were monitored continuously during field operations, the appropriate values of $r_{\mathrm{c}}$ can be computed at each thermistor depth. $P$ and $v_{\mathrm{p}}$ did not change rapidly with probe depth so that in the neighbourhood of each thermistor the hole was nearly cylindrical with $r_{\mathrm{c}}$ given by Equation (I). Comparisons of theoretical cooling curves and data recorded at three sites on Trapridge Glacier (Jarvis, unpublished) show good agreement, and the corrected Steele Glacier temperatures are expected to be within $\pm 0.2^{\circ} \mathrm{C}$ of the true equilibrium values. The observed ten-day temperatures and the values corrected to equilibrium are given in Table I.

\begin{tabular}{|c|c|c|}
\hline $\begin{array}{c}\text { Thermistor } \\
\text { depth } \\
\mathrm{m}\end{array}$ & $\begin{array}{c}\text { Measured } \\
\text { ice temperature } \\
{ }^{\circ} \mathbf{C}\end{array}$ & $\begin{array}{l}\text { Corrected } \\
\text { temperature } \\
{ }^{\circ} \mathrm{C}\end{array}$ \\
\hline 26 & $-\mathrm{I} .54$ & -1.85 \\
\hline 33 & $-0.9^{6}$ & $-\mathrm{I} .44$ \\
\hline $4^{\circ}$ & -1.14 & $-\mathrm{I} .55$ \\
\hline 47 & -0.54 & -1.36 \\
\hline 54 & $-1.3^{8}$ & $-\mathrm{I} .75$ \\
\hline $6 \mathrm{I}$ & -2.14 & -2.45 \\
\hline 70 & -3.90 & $-4.1 \mathrm{I}$ \\
\hline 82 & -4.77 & $-4.9^{8}$ \\
\hline $9^{2}$ & -5.43 & -5.65 \\
\hline IOO & $\begin{array}{r}-5.88 \\
\end{array}$ & -6.10 \\
\hline го6 & -6.13 & -6.35 \\
\hline 112 & $-6.4 \mathrm{I}$ & -6.63 \\
\hline 114 & -6.46 & -6.68 \\
\hline
\end{tabular}

In the region of the drill site, the upper $114 \mathrm{~m}$ of the glacier is cold but the temperature profile is unusual and unexpected. Below $50 \mathrm{~m}$ the ice cools with depth suggesting the presence of a heat source near $40 \mathrm{~m}$. No similar anomaly has been observed on the nearby Rusty and Trapridge Glaciers, two surge-type glaciers in the quiescent phase (Classen and Clarke, I97I; Clarke and Goodman, in press; Jarvis and Clarke, unpublished). Geothermal heat causes the temperature in these cold glaciers to increase with depth. Thus the anomaly does not appear to reflect a regional climatic amelioration but is probably a consequence of the Steele Glacier's most recent surge. The ice thickness is thought to be considerably greater than $114 \mathrm{~m}$, so a continued temperature decrease to the glacier bed seems unlikely. If one makes the reasonable assumption that prior to the surge the temperature increased monotonically with depth, the upper I I $4 \mathrm{~m}$ must have been colder than $-6.5^{\circ} \mathrm{C}$ before the advance began. Measurements on the Rusty and Trapridge Glaciers suggest that $-8.0^{\circ} \mathrm{C}$ is a good estimate of the mean annual surface temperature. 
The apparent heat source near $40 \mathrm{~m}$ must be localized in the vertical sense and be of sufficient strength to have maintained the observed anomaly for the six or seven years since the surge onset. Available energy sources are internal viscous heating, friction from sliding along shear planes, and internal water cavities. Thermal anomalies might also be generated by advective heat transfer or large displacements along shear planes. Viscous heating and sliding friction are insufficient to produce the observed effect. Aerial photographs analyzed by Stanley ( 1969 ) show that the drill site was in a zone of surface lowering and active extensional flow throughout the surge so that neither advection nor ice displacement along shear planes could account for the anomalously warm temperatures near $40 \mathrm{~m}$. (Even in a region of passive compressive flow a temperature anomaly of $6.0^{\circ} \mathrm{C}$ would require an unreasonably large upward mass transport.) We therefore conclude that englacial water cavities are the most probable energy source.

During the Steele Glacier surge, crevasses as wide as $20 \mathrm{~m}$ and as deep as $100 \mathrm{~m}$ were not uncommon. Since extensive crevassing reduces albedo and inhibits surface run-off, large quantities of melt-water can enter newly formed crevasses and gain access to considerable depths within the glacier. Collins (Nielsen, I969, discussion on p. 960) remarked that this should have a noticeable effect on the temperature of a cold surge-type glacier and speculated that on some surging glaciers water might even be admitted to the glacier bed. Our observations support the first suggestion but not the latter.

\section{Crevasse model}

To evaluate the thermal effects of trapped water in a cold crevassed glacier, a twodimensional, time-dependent numerical model was developed. The ice temperature $T$ was assumed to be a function of the space variables $x$, measured in the direction of flow, and $y$, the depth measured perpendicular to the glacier surface. Prior to the surge onset at $t=0$ the glacier surface was assumed to be a plane maintained at a temperature which varied sinusoidally with time. (As might be expected the time-dependence of the surface boundary condition played a negligible role in the final results except near the surface-air boundaries.) The temperature at a depth $d^{\star}$ far below the glacier surface was held constant at $T_{\mathrm{d}}$. Therefore the pre-surge temperature profile is linear with depth except near the glacier surface, and the temperature gradient is simply the apparent geothermal gradient.

At the surge onset, severe crevassing of the upper surface occurs, allowing melt water to partially fill the crevasses. Both the crevasse formation and water filling were assumed to occur instantaneously at $t=0$. This assumption is justified if one is interested in ice temperatures several years after the surge has terminated. By that time the exact details of crevasse formation and water filling have an insignificant effect on the observed temperatures. For simplicity the crevasse field was assumed to be spatially periodic with infinitely long, symmetric crevasses at constant separation (Fig. 2). The initial shape of each crevasse was taken as a triangular wedge, although freezing of the trapped water modified the cross section with time. These assumptions yield a high degree of symmetry and it is only necessary to calculate the ice temperatures within the shaded region of Figure 2 to obtain the complete temperature solution.

Because the crevasses are assumed to contain water, the usual arguments predicting maximum crevasse depths based on creep rates do not apply (Weertman, 1971). When the crevasse is open at the surface, hydrostatic pressure of the trapped water resists creep closure; when it is sealed by surface freezing, incompressibility of the water cavity prevents creep closure entirely so that freezing is the dominant mechanism of crevasse closure.

The model parameters are defined as illustrated in Figure 3. The crevasse separation $S$ was estimated from an aerial photograph of the drilling site taken in 1970 after termination of the surge (Fig. I, inset). The crevasse width $W$ could only be crudely estimated from the 


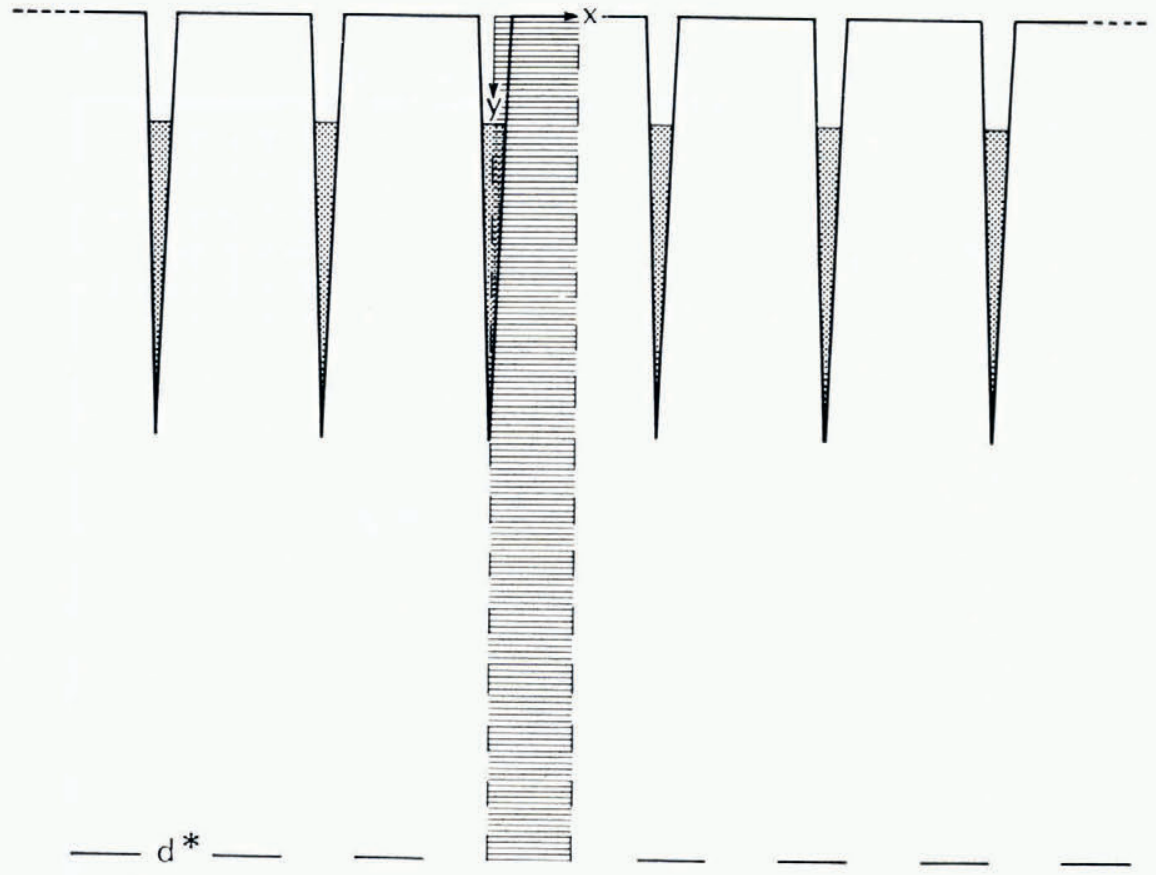

Fig. 2. Model of crevasse field. Owing to spatial periodicity temperatures need only be evaluated in the shaded region.

same photograph, but this parameter proved to have a minor influence on the temperature distributions calculated. $T_{\mathrm{d}}$ was chosen so that the initial temperature profile agreed closely with observation at the deepest points, where ice temperatures were assumed to be relatively unaffected by the thermal disturbance of the upper ice (Fig. 4). The crevasse depth $d_{\mathrm{c}}$ could not be estimated and was adjusted to give the best fit to the data. Finally the depth to the initial water surface $d_{\mathrm{w}}$ was taken to be ${ }_{5} \mathrm{~m}$, the approximate depth to the present crevasse bottoms which are interpreted as ice bridges.

The thermal effects of the surge are complex and unknown. Hence, to isolate the effects of crevassing we shall omit the advection and heat generation terms from the diffusion equation and solve

$$
\frac{\partial^{2} T}{\partial x^{2}}+\frac{\partial^{2} T}{\partial y^{2}}=\frac{1}{\kappa} \frac{\partial T}{\partial t}
$$

(where $\kappa$ is the thermal diffusivity of ice) subject to the appropriate boundary conditions. At the moving ice-water interface the boundary condition is somewhat complicated and makes the crevasse closure problem a close relative of the classical Stefan problem (Carslaw and Jaeger, 1959). Conservation of thermal energy at the phase boundary gives

$$
K \nabla T-K_{\mathrm{w}} \nabla T_{\mathrm{w}}=\rho_{\mathrm{w}} L \boldsymbol{v}
$$

where $K$ is the thermal conductivity of ice, $K_{\mathrm{w}}$ the thermal conductivity of water, $T_{\mathrm{w}}$ the water temperature, $\rho_{\mathrm{w}}$ the density of water, ${ }^{*} L$ the latent heat of fusion and $v$ the velocity of

* The traditional Stefan problem deals with two-phase boundaries and constant density $\rho$ across the interface. In the crevasse closure problem the two phases have different densities and the question arises as to which value of $\rho$ should be used. All the latent energy of the water must go into the glacier ice. Some of this energy will initially be stored as elastic strain, but eventually is converted to thermal energy as the strained ice relaxes. Thus to ensure conservation of energy we take the density in Equation (3) to be that of water $\rho_{w}$, although we ignore the details of elastic strain in our calculations. 


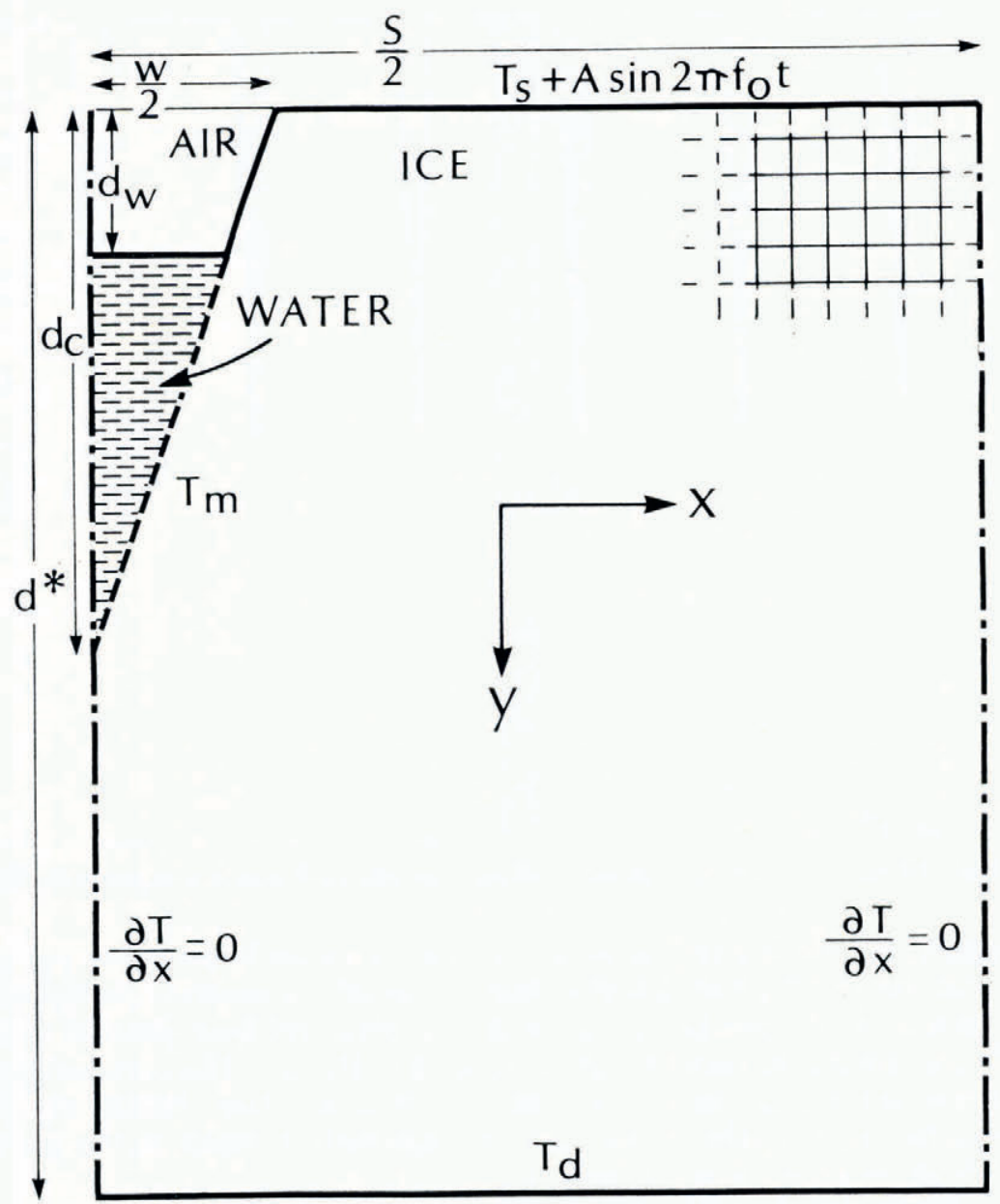

Fig. 3. Finite-difference grid illustrating model parameters and boundary conditions.

the interface. The water can be assumed isothermal at $T_{\mathrm{m}}=0^{\circ} \mathrm{C}$ so that $K_{\mathrm{w}} \nabla T_{\mathrm{w}}$ vanishes. The time-dependent crevasse half-profile $X(y, t)$ as obtained from Equation (3) is

$$
X(y, t)=X(y, \mathrm{o})-\frac{\kappa}{\rho_{\mathrm{W}} L} \int_{\mathrm{o}}^{t}\left\{\left|\nabla T_{i}(x, y, t)\right| / \cos \alpha_{i}(x, y, t)\right\} \mathrm{d} t
$$

where $\alpha$ is the angle between the vector $-\nabla T$ and the $x$-axis, and the subscript $i$ refers to points along the interface.

The remaining boundary conditions are straight-forward. At all ice-air interfaces the temperature is $T_{\mathrm{s}}+A \sin 2 \pi f_{0} t$ where $T_{\mathrm{s}}$ is the mean annual temperature, $A$ is the amplitude of annual temperature variation and $f_{0}=\mathrm{I}$ cycle $\mathrm{a}^{-1}$. At depth $d^{\star}$ well below the region influenced by the crevasses the temperature is $\mathcal{T}_{\mathrm{d}}$. The air-water interface is assumed to vanish almost instantly and is replaced by an ice-air interface. At the vertical boundaries of the grid the horizontal heat flux vanishes by virtue of the spatial periodicity of crevassing; thus $\partial T / \partial x$ vanishes at these boundaries. 
TEMPERATURE $\left({ }^{\circ} \mathrm{C}\right)$

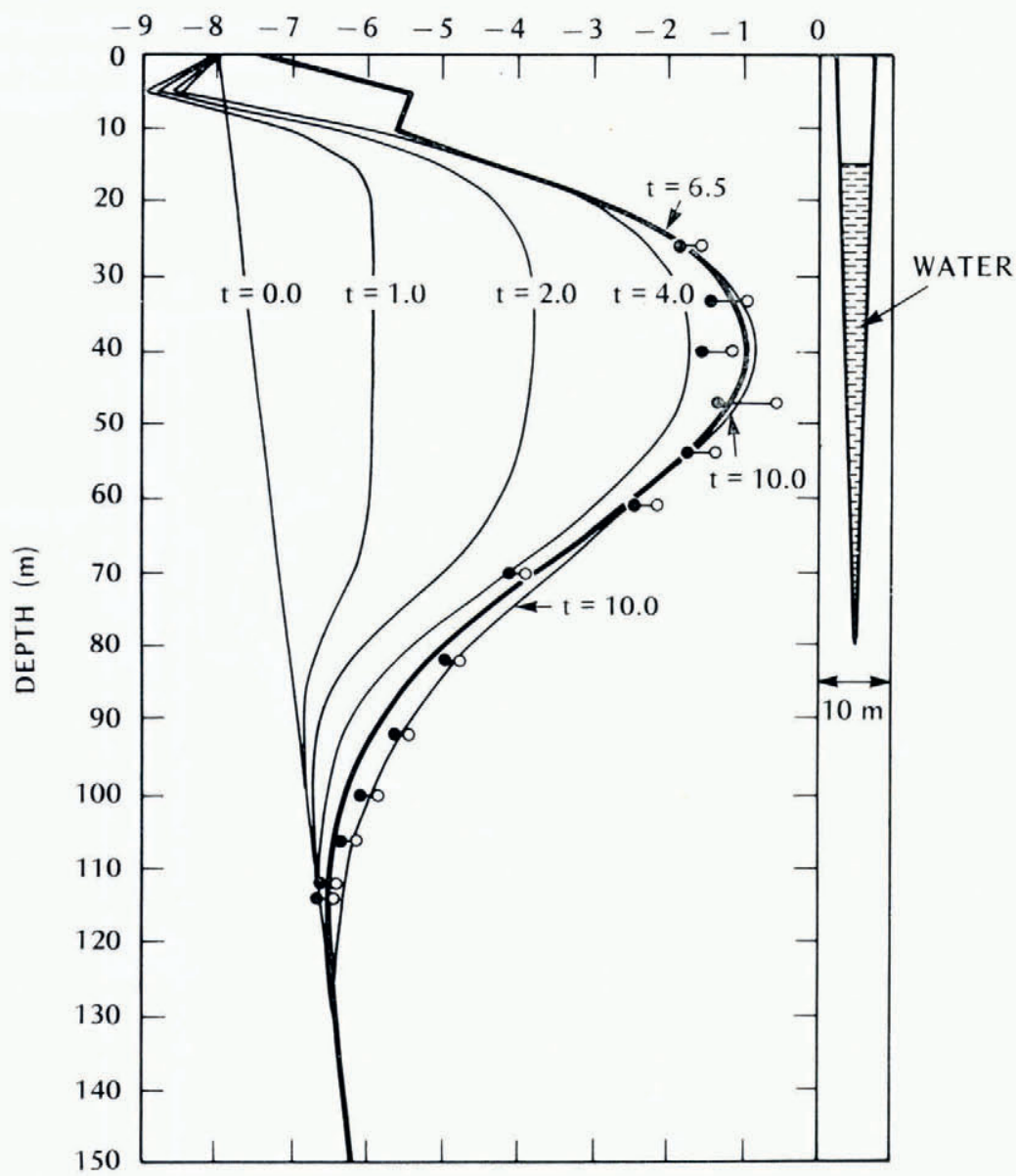

Fig. 4. Theoretical temperature profiles $15 \mathrm{~m}$ from nearest crevasse at various times given in years. Measured Steele Glacier temperatures are indicated by open circles; temperatures corrected to equilibrium are indicated by solid circles.

Equation (2) was written as a finite-difference equation and solved by the PeacemanRachford implicit alternating-direction technique (Peaceman and Rachford, I955; Forsythe and Wasow, I960; Carnahan, and others, I969). Details of this numerical method are given in Appendix B. The time evolution of the crevasse cross-section was computed by finitedifference evaluation of Equation (4) at each time step.

\section{Results}

For reasonable parameter values the model predicts ice temperatures which agree well with those measured in Steele Glacier. Theoretical temperature profiles from the model, with parameters as listed in Table II, are displayed in Figures 4 and 5, along with the observed temperature profile. In these calculations the crevasse spacing was taken as $30 \mathrm{~m}$ so that $15 \mathrm{~m}$ is the maximum possible distance between a drilling site and the central plane of the nearest crevasse. Figure 4 is a sequence of profiles, midway between crevasses, at successive times ranging from I-Io years after crevasse formation. The 6.5 year profile corresponds to 
the time of thermal drilling on Steele Glacier. Temperatures predicted at various distances from the crevasse at $t=6.5$ years are shown in Figure 5 ; the curves are closely similar for distances $9^{-1} 5 \mathrm{~m}$ from the crevasse. The model, then, seems capable of explaining the gross features of the observed anomaly provided the drilling site was located $15 \pm 6 \mathrm{~m}$ from the nearest crevasse at a time $7 \pm 3$ years after the surge onset. Neither of these conditions is very stringent and both are satisfied by the drill site.

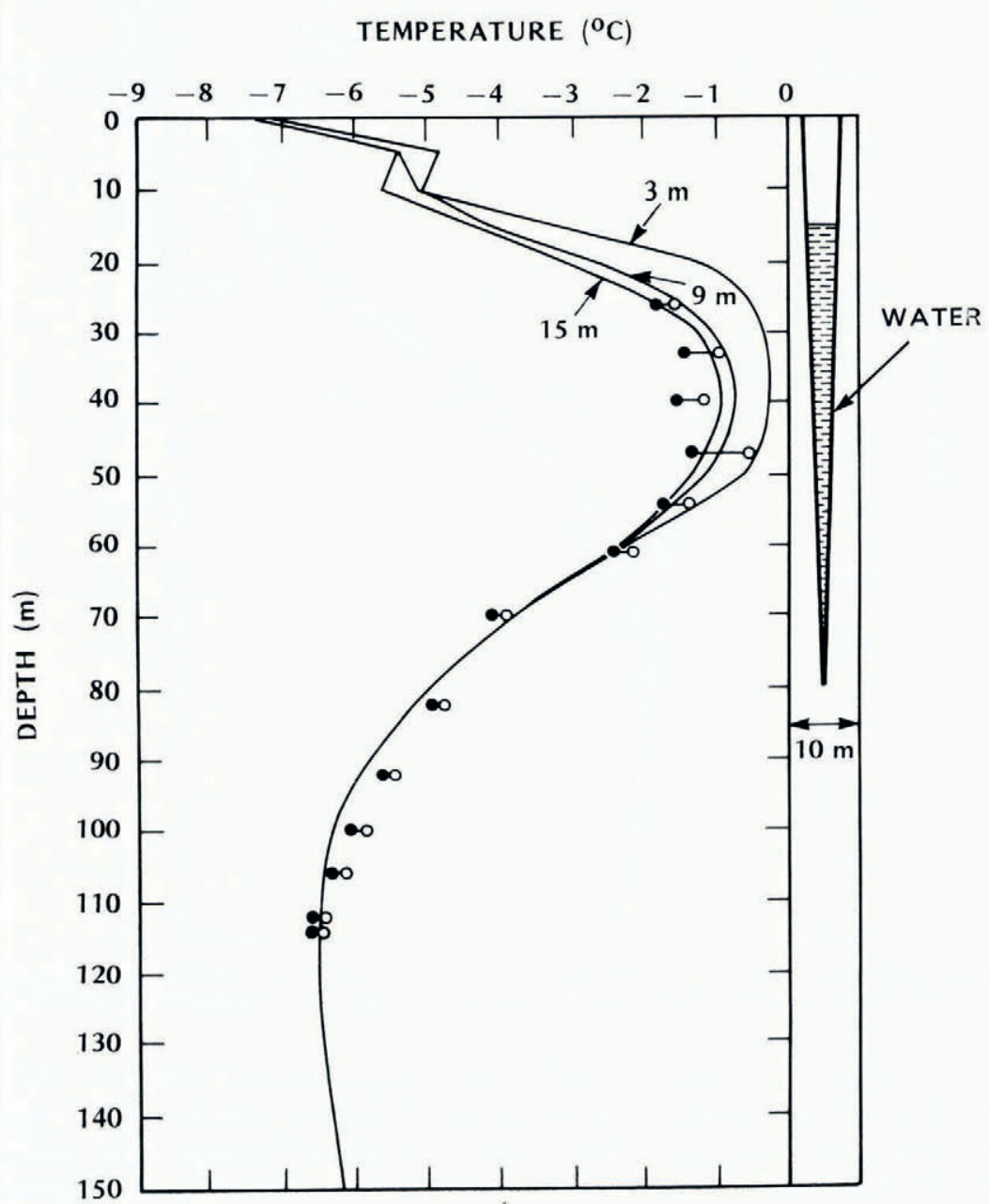

Fig. 5. Theoretical temperature profiles at various distances from the nearest crevasse at $t=6.5$ years. Measured Steele Glacier temperatures indicated by open circles; temperatures corrected to equilibrium are indicated by solid circles.

The model also presents an interesting study of crevasse closure in cold ice. Since Equation (4) was solved at each time step, a plot of $X(y, t)$ gives a graphic illustration of crevasse closure (Fig. 6). Surprisingly slow closure takes place after the first four years. However, Figure 4 shows that after four years the ice between the water-filled portions of the crevasses, even at the furthest points from them, has warmed to within two degrees of the water temperature. Consequently horizontal temperature gradients are very small and heat flux from the crevasse is minimal, except at the top and bottom of each water cavity, where vertical heat flux can 
carry energy away from the crevasse. This slow closure is due to the close spacing of the large crevasses, which concentrates the thermal energy into a small volume. Increasing the crevasse separation was found to greatly increase the rate of closure; an isolated crevasse could be studied by choosing a very large crevasse spacing.

TABle II. NUMERICAL INPUTS FOR CREVASSE MODEL

\begin{tabular}{|c|c|c|}
\hline \multicolumn{3}{|l|}{ Model parameters } \\
\hline Crevasse separation & $S$ & $30 \mathrm{~m}$ \\
\hline Crevasse width & $W$ & $5 \mathrm{~m}$ \\
\hline Crevasse depth & $d_{\mathrm{c}}$ & $80 \mathrm{~m}$ \\
\hline Depth to water surface & $d_{\mathrm{w}}$ & $15 \mathrm{~m}$ \\
\hline Mean surface temperature & $T_{\mathrm{s}}$ & $-8.0^{\circ} \mathrm{C}$ \\
\hline Amplitude of annual temperature variation & $A$ & $8.0^{\circ} \mathrm{C}$ \\
\hline Deep ice boundary condition & $\mathcal{T}_{\mathrm{d}}$ & $-6.25^{\circ} \mathrm{C}$ \\
\hline Depth to deep ice boundary & $d^{\star}$ & $150 \mathrm{~m}$ \\
\hline Initial temperature gradient & $G$ & I $1.7 \mathrm{deg} \mathrm{\textrm {km } ^ { - 1 }}$ \\
\hline \multicolumn{3}{|l|}{ Physical constants } \\
\hline Ice density & $\rho$ & $9.0 \times 10^{2} \mathrm{~kg} \mathrm{~m}^{-3}$ \\
\hline Water density & $\rho_{\mathrm{w}}$ & $1.0 \times 10^{3} \mathrm{~kg} \mathrm{~m}^{-3}$ \\
\hline Thermal conductivity of ice & $\kappa$ & $2.219 \mathrm{~W} \mathrm{~m}^{-1} \mathrm{deg}^{-1}$ \\
\hline Specific heat of ice & C & $2.101 \times 10^{3} \mathrm{~J} \mathrm{~kg}^{-1} \mathrm{deg}^{-1}$ \\
\hline Thermal diffusivity of ice & $\kappa$ & $1.173 \times 10^{-6} \mathrm{~m}^{2} \mathrm{~s}^{-1}$ \\
\hline Latent heat of fusion in ice & $L$ & $3.337 \times 10^{5} \mathrm{~J} \mathrm{~kg}^{-1}$ \\
\hline \multicolumn{3}{|l|}{ Finite difference variables } \\
\hline Horizontal spatial increment & $\Delta x$ & $0.50 \mathrm{~m}$ \\
\hline Vertical spatial increment & $\Delta y$ & $5.00 \mathrm{~m}$ \\
\hline \multicolumn{3}{|l|}{ Time increment } \\
\hline$(t \leqslant 1.0$ year $)$ & $\tau$ & 0.01 year \\
\hline$(t>1.0$ year $)$ & $\tau$ & 0.02 year \\
\hline Spatial grid size & & $31 \times 31$ \\
\hline
\end{tabular}

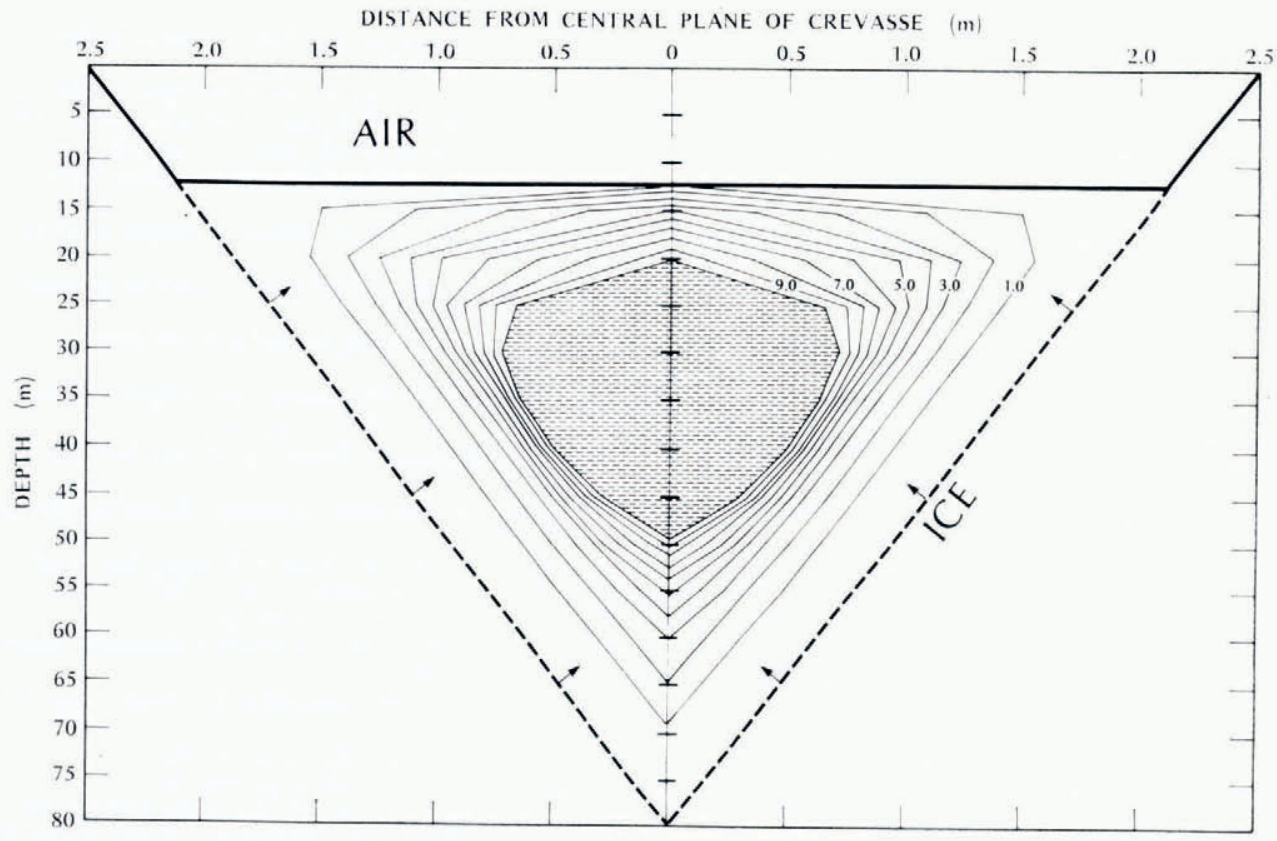

Fig. 6. Closure by refreezing of a water-filled crevasse in cold ice. Crevasse cross-sections are indicated at times given in years. 


\section{Concluding Remarks}

Our modelling study indicates that partially water-filled crevasses can have a significant effect on the temperature distribution within a cold glacier and that the observed temperature anomaly in Steele Glacier is probably due to this energy source. Similar anomalies are likely to occur in other cold surge-type glaciers and remain for many years after the active phase terminates. Thin surging glaciers would be particularly sensitive to such a major disturbance of their temperature regime.

\section{ACKNOWLEDGEMENTS}

We thank B. Chandra, B. B. Narod and K. D. Schreiber for assistance in field preparations, S. G. Collins, R. H. Ragle, P. Upton and W. A. Wood of the Arctic Institute of North America for encouragement and logistic support, and M. F. Meier, A. S. Post and A. D. Stanley for providing photographs and important unpublished information about the Steele Glacier surge. We are especially grateful to R. Metcalfe who proved to be an invaluable assistant in the field. Financial support was provided by the University of British Columbia, Environment Canada and the National Research Council (Canada).

MS. received 12 July 1973 and in revised form 23 November 1973

\section{REFERENCES}

Bayrock, L. A. 1967 . Catastrophic advance of the Steele Glacier, Yukon, Canada. Alberta University. Boreal Institute. Occasional Publication No. 3.

Carnahan, B., and others. 1969. Applied numerical methods, by B. Carnahan, H. A. Luther and J. O. Wilkes. New York, John Wiley and Sons, Inc.

Carslaw, H. S., and Jaeger, J. C. 1959. Conduction of heat in solids. Second edition. Oxford, Clarendon Press.

Clarke, G. K. C., and Goodman, R. In press. Radio echo soundings and ice temperature measurements in a surge-type glacier. Fournal of Glaciology.

Classen, D. F., and Clarke, G. K. C. 197I. Basal hot spot on a surge type glacier. Nature, Vol. 229, No. 5285, p. $48 \mathrm{r}-83$.

Classen, D. F., and Clarke, G. K. C. 1972. Thermal drilling and ice-temperature measurements in the Rusty Glacier. (In Bushnell, V. C., and Ragle, R. H., ed. Icefield Ranges Research Project. Scientific results. Vol. 3. New York, American Geographical Society; Montreal, Arctic Institute of North America, p. 103-16.)

Forsythe, G. E., and Wasow, W. R. 1960. Finite difference methods for partial differential equations. New York, John Wiley and Sons, Inc.

Jarvis, G. T. Unpublished. Thermal studies related to surging glaciers. [M.Sc. thesis, University of British Columbia, 1973.]

Jarvis, G. T., and Clarke, G. K. C. Unpublished. The thermal regime of Trapridge Glacier and its relevance to glacier surging.

Nielsen, L. E. 1969. The ice-dam, powder-flow theory of glacier surges. Canadian Journal of Earth Sciences, Vol. 6 , No. 4, Pt. 2, p. 955-61.

Peaceman, D. W., and Rachford, H. H., jr. 1955. The numerical solution of parabolic and elliptic differential equations. Fournal of the Society for Industrial and Applied Mathematics, Vol. 3, No. I, p. 28-4I.

Sharp, R. P. I 95 I. The glacial history of Wolf Creek, St. Elias Range, Canada. Journal of Geology, Vol. 59, No. 2, p. $97^{-1} 17$.

Stanley, A. D. 1969 . Observations of the surge of Steele Glacier, Yukon Territory, Canada. Canadian Fournal of Earth Sciences, Vol. 6, No. 4, Pt. 2, p. 819-30.

Thomson, S. 1972. Movement observations on the terminus areas of the Steele Glacier, Yukon, July 1967. (In Bushnell, V. C., and Ragle, R. H., ed. Icefield Ranges Research Project. Scientific results. Vol. 3. New York, American Geographical Society; Montreal, Arctic Institute of North America, p. 29-37.)

Weertman, J. 1971. Theory of water-filled crevasses in glaciers applied to vertical magma transport beneath oceanic ridges. Fournal of Geophysical Research, Vol. 76, No. 5, p. i $171-83$.

Wood, W. A. 1936. The Wood Yukon expedition of 1935: an experiment in photographic mapping. Geographical Review, Vol. 26, No. 2, p. 228-46.

Wood, W. A. 1967[a]. Glaciology: chaos in nature. Explorers fournal, Vol. 45, No. 2, p. 79-87.

Wood, W. A. I967[b]. Steele Glacier surge. American Alpine Journal, Vol. 15, No. 2, p. 279-81.

Wood, W. A. 1972. Steele Glacier, 1935-1968. (In Bushnell, V. C., and Ragle, R. H., ed. Icefield Ranges Research Project. Scientific results. Vol. 3. New York, American Geographical Society; Montreal, Arctic Institute of North America, p. I-8.) 


\section{APPENDIX A}

\section{FREEZING OF A GYLINDRICAL WATER-FILLED HOLE IN COLD ICE}

To compute hole closure rates and cooling curves for a water-filled cylindrical hole in cold ice, diffusion equations of the form

$$
\frac{\partial^{2} T}{\partial r^{2}}+\frac{\mathrm{I}}{r} \frac{\partial T}{\partial r}=\frac{\mathrm{I}}{\kappa} \frac{\partial T}{\partial t}
$$

must be solved in ice and water. At the ice-water interface the boundary conditions are

and

$$
\begin{aligned}
& K \frac{\partial T}{\partial r}-K_{\mathrm{w}} \frac{\partial T_{\mathrm{w}}}{\partial r}=\rho_{\mathrm{w}} L \frac{\mathrm{d} r_{\mathrm{e}}}{\mathrm{d} t} \\
& T\left(r_{\mathrm{c}}, t\right)=T_{\mathrm{w}}\left(r_{\mathrm{e}}, t\right)=T_{\mathrm{m}}
\end{aligned}
$$

where $r_{\mathrm{c}}$ is the radius of the water-filled cylinder and $T_{\mathrm{m}}$ the melting temperature of ice. The remaining boundary conditions are

and

$$
\begin{gathered}
\lim _{r \rightarrow \infty} T(r, t)=T_{\mathrm{o}} \\
2 \pi r_{0} K_{\mathrm{w}} \frac{\partial T_{\mathrm{w}}\left(r_{0}, t\right)}{\partial r}=-q_{\mathrm{l}}(t)
\end{gathered}
$$

where $T_{0}$ is the ambient ice temperature, $q_{1}(t)$ the strength of a line heating source, and $r_{0}$ its radius. Boundary condition $\left(\mathrm{A}_{5}\right)$ allows the possibility of evaluating the effect of ohmic dissipation in the power cable leading to the thermal probe. In the calculations discussed above $q_{1}$ was negligible and the water phase was essentially isothermal at temperature $T_{\mathrm{m}}$. Solutions for iarge values of $q_{1}$ have also been computed to determine whether line heating can be used to inhibit hole closure during thermal drilling.

In passing to a finite-difference approximation of $\left(\mathrm{AI}_{\mathrm{I}}\right)$ it is convenient to introduce a logarithmic grid by the transformation $R=\ln r$; thus (AI) becomes

$$
\exp (-2 R) \frac{\partial^{2} T}{\partial R^{2}}=\frac{1}{\kappa} \frac{\partial T}{\partial t}
$$

with $T=T(R, t)$, and $\left(\mathrm{A}_{2}\right)$ gives

$$
\frac{\mathrm{d} R_{\mathrm{c}}}{\mathrm{d} t}=\frac{\exp \left(-2 R_{\mathrm{c}}\right)}{\rho_{\mathrm{w}} L}\left\{K \frac{\partial T}{\partial R}-K_{\mathrm{w}} \frac{\partial T_{\mathrm{w}}}{\partial R}\right\}
$$

where $R_{\mathrm{c}}=\ln r_{\mathrm{c}}$.

Following the Crank-Nicolson approach, the solutions of Equation (A6) for times $t$ and $t+\tau$ are averaged to reduce the discretization error giving as the finite-difference equation in the $i$ th medium

$$
\begin{aligned}
-\lambda_{i} \theta \exp (-2 R) & T_{i}(R-h, t+\tau)+\left[\mathrm{I}+2 \lambda_{i} \theta \exp (-2 R)\right] T_{i}(R, t+\tau)- \\
& -\lambda_{i} \theta \exp (-2 R) T_{i}(R+h, t+\tau)=\lambda_{i}(\mathrm{I}-\theta) \exp (-2 R) T_{i}(R-h, t)+ \\
& +\left[\mathrm{I}-2 \lambda_{i}(\mathrm{I}-\theta) \exp (-2 R)\right] T_{i}(R, t)+\lambda_{i}(\mathrm{I}-\theta) \exp (-2 R) T_{i}(R+h, t)
\end{aligned}
$$

where $h$ is the space increment of the logarithmic grid, $\tau$ the time increment, $\lambda_{i}=\kappa_{i} \tau / h^{2}$, and $\theta$ is an averaging parameter which is usually set to the value $\theta=0.5$. The variables $R$ and $t$ take discrete values $m h$ and $n \tau$ respectively, where $m$ and $n$ are integers. In Equation (A8) the right-hand side terms are known and the left-hand side terms are unknown. If similar equations are written at each grid point one obtains a tridiagonal set of linear equations which can be solved for the unknown temperatures $T(R, t+\tau)$.

Infinitely large grids are not feasible so that the boundary condition $\left(\mathrm{A}_{4}\right)$ is replaced by $T\left(R_{\max }, t\right)=T_{0}$ where $R_{\max }$ is some suitably large value of $R=\ln r$. At $R_{0}=\ln r_{0}$ we have the condition

$$
2 \pi K_{\mathrm{w}} \partial T\left(R_{0}, t\right) / \partial R=-q_{1}(t)
$$

and at $R_{\mathrm{c}}=\ln r_{\mathrm{c}}$, the ice-water interface, $T\left(R_{\mathrm{c}}, t\right)=T_{\mathrm{m}}$. The finite-difference equations (A8) are solved subject to the above boundary conditions and the migration of the ice-water interface is evaluated at each time step by substituting finite-difference approximations of $\partial T\left(R_{\mathrm{c}}, t\right) / \partial t$ and $\partial T_{\mathrm{w}}\left(R_{\mathrm{c}}, t\right) / \partial t$ into Equation $(\mathrm{A} 2)$. When the condition $R_{\mathrm{c}}<R_{0}$ is satisfied, the water phase is considered to vanish and a simple one-phase problem results.

\section{APPENDIX B}

\section{Peaceman-Raghford numerical method}

For a finite-difference grid with space intervals $\Delta x, \Delta y$ and time step $\tau$, the standard implicit finite-difference approximation to Equation (2) yields

$$
\begin{aligned}
-\lambda_{x} T(x-\Delta x, y, t+\tau)-\lambda_{y} T(x, y-\Delta y, t & +\tau)+\left(\mathrm{I}+2 \lambda_{x}+2 \lambda_{y}\right) T(x, y, t+\tau)- \\
& -\lambda_{y} T(x, y+\Delta y, t+\tau)-\lambda_{x} T(x+\Delta x, y, t+\tau)=T(x, y, t)
\end{aligned}
$$


where $\lambda_{x}=\kappa \tau /(\Delta x)^{2}, \lambda_{y}=\kappa \tau /(\Delta y)^{2}$, and the variables $x, y$, and $t$ have the discrete values $x=i \Delta x, y=j \Delta y$, and $t=n \tau$ for integer values of $i, j$, and $n$. Equations $\left(\mathrm{B}_{1}\right)$ are implicit in both $x$ - and $y$-directions and have five unknowns per equation. Direct solution of this system of equations requires the inversion of a large five-band diagonal matrix and is computationally expensive.

In the Peaceman-Rachford implicit-alternating-direction method, two systems of equations are used in turn over successive time steps of duration $\tau / 2$. The first equation is implicit in the $x$-direction only, the second in the $y$-direction. Using the notation $T^{\star}(x, y)$ to represent the intermediate values of $T$ half-way through the time step $\tau$, for implicit $x$ we have

$$
\begin{aligned}
-T^{\star}(x-\Delta x, y)+2\left(\mathrm{I} / \lambda_{x}+\mathrm{I}\right) & T^{\star}(x, y)-T^{\star}(x+\Delta x, y) \\
& =\lambda_{y} / \lambda_{x} T(x, y-\Delta y, t)+2\left(\mathrm{I} / \lambda_{x}-\lambda_{y} / \lambda_{x}\right) T(x, y, t)+\lambda_{y} / \lambda_{x} T(x, y+\Delta y, t),
\end{aligned}
$$

and for implicit $y$

$$
\begin{array}{r}
\left.-T(x, y-\Delta y, t+\tau)+2\left(\mathrm{I} / \lambda_{y}+\mathrm{I}\right) T(x, y, t+\tau)-T_{i} x, y+\Delta y, t+\tau\right) \\
=\lambda_{x} / \lambda_{y} T^{\star}(x-\Delta x, y)+2\left(\mathrm{I} / \lambda_{y}-\lambda_{x} / \lambda_{y}\right) T^{\star}(x, y)+\lambda_{x} / \lambda_{y} T^{\star}(x+\Delta x, y) .
\end{array}
$$

The systems of equations $\left(B_{2}\right)$ and $\left(\Gamma_{3}\right)$ have only three unknowns per equation and the implicit solution of each system merely involves the inversion of tridiagonal matrices for which simple and efficient algorithms are readily available.

Holding $y$ constant, one equation of the form (B2) is written for each value of $x$ and the resultant tridiagonal system of equations is solved simultaneously. Equations (B2) are solved in this manner once for each value of $y$ to generate the complete solution $T^{\star}(x, y)$. Equations $\left(\mathrm{B}_{3}\right)$ are now solved by substituting the solution $T^{\star}(x, y)$ obtained from $\left(\mathrm{B}_{2}\right)$ into $\left(\mathrm{B}_{3}\right)$. Holding $x$ constant, one equation of the form $\left(\mathrm{B}_{3}\right)$ can be written $\mathrm{f}(\mathrm{r}$ each value of $y$ and the new system of equations solved simultaneously. Equations ( $\left.\mathrm{B}_{3}\right)$ are solved once for each value of $x$ to generate $T(x, y, t+\tau)$, the temperature distribution advanced one full time step. This procedure is unconditionally stable for any value of $\tau$ and the discretization error is $O\left[\tau^{2}+(\Delta x)^{2}\right]$. 